\title{
Pneumomediastinum: a complication of reinserting a dislodged tracheostomy
}

\author{
Muzzammil Ali
}

Intensive Care Unit, New Cross Hospital, Wolverhampton, UK

\section{Correspondence to \\ Dr Muzzammil Ali} muzzammil.ali@nhs.net

Accepted 22 August 2018

\section{DESCRIPTION}

A 54-year-old woman with a background of obesity and hypertension presented following a pulseless electrical activity (PEA) cardiac arrest. Cardiopulmonary resuscitation (CPR) was commenced on arrival of the paramedics and she was intubated and ventilated (figure 1). Return of spontaneous circulation was achieved in the emergency department following a total of $45 \mathrm{~min}$ of CPR. No clear cause of her arrest was identified. She was transferred to the intensive care unit (ICU) for post-arrest management.

Seizure activity off of sedation necessitated further investigation. Her CT head was unremarkable, but her lumbar puncture showed features in keeping with meningitis. She was therefore treated with antibiotics and antiepileptics. Her cerebrospinal fluid viral PCR and blood HIV tests were negative.

Although appropriate seizure control was achieved, as evident on electroencephalogram monitoring, her Glasgow Coma Score (GCS) remained low off of sedation. The decision was eventually made to perform a surgical tracheostomy. This was uneventful. She embarked on a path of respiratory weaning and later was spontaneously breathing on room air. An MRI of her head showed features in keeping with global hypoxic brain injury. The neurology team deemed this to be secondary to her long downtime.

One evening when she was being rolled by the nursing staff, her tracheostomy was accidentally dislodged 2 weeks after it was inserted. Her oxygen saturation $\left(\mathrm{SpO}_{2}\right)$ dropped from $100 \%$ to $92 \%$.

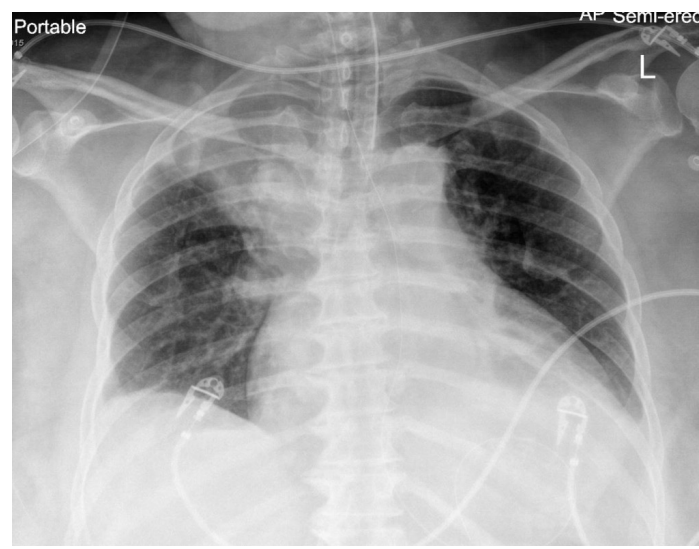

Figure 1 Initial chest radiograph following return of spontaneous circulation, with endotracheal tube present (included as a baseline for comparison).

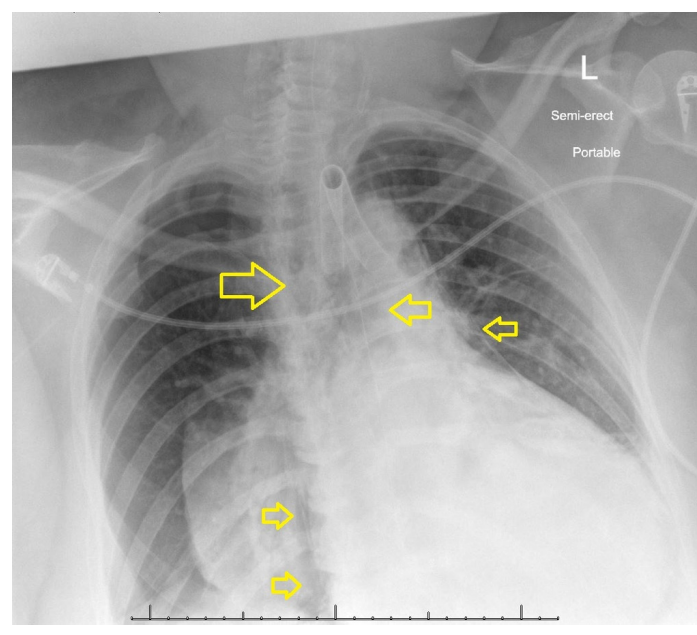

Figure 2 Features of pneumomediastinum with radiolucent streaks in the mediastinum (arrows).

Because she was spontaneously breathing, oxygen was provided via a face mask. Her $\mathrm{SpO}_{2}$ increased to $100 \%$.

The tracheostomy was removed and a suction catheter was passed into the trachea. An attempt to then railroad a new tracheostomy via the suction catheter was unsuccessful. A bougie was used instead as a railroading apparatus. This was performed, but no ventilation was achieved via this new tracheostomy. A quick bronchoscopy was performed which showed mediastinal fat; the reinserted tracheostomy was not in the trachea but was in the mediastinum.

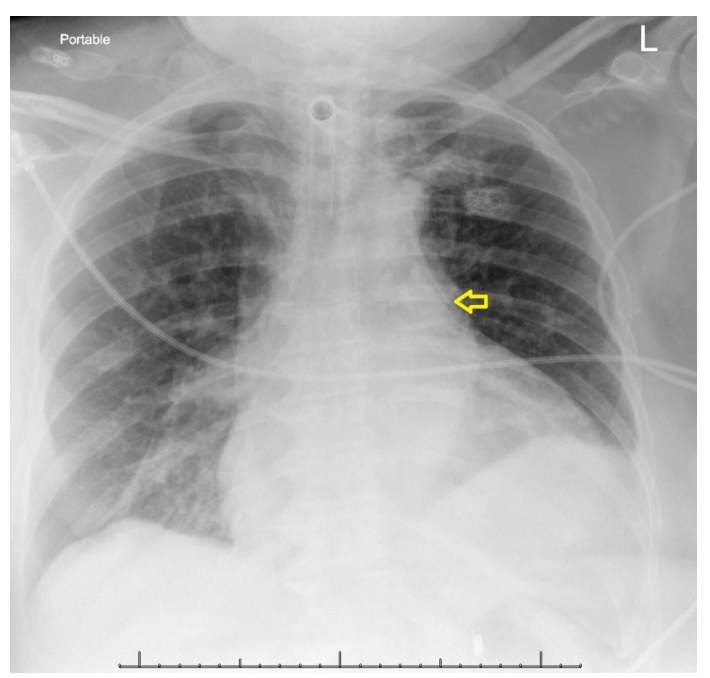

Figure 3 Less air in the mediastinum with some residual seen on the left heart border (arrow). 
A chest X-ray showed features in keeping with pneumomediastinum (figure 2). The decision was made to perform endotracheal intubation (rapid sequence induction). This was successful and an appropriate $\mathrm{SpO}_{2}$ was achieved with high ventilatory pressures.

The cardiothoracic team deemed a conservative management approach as appropriate. She was taken to the emergency theatre that evening and a new surgical tracheostomy was inserted by the ear, nose and throat (ENT) team. Her weaning plan resumed and she was later self-ventilating on room air. Her chest X-ray changes had improved a day later (figure 3).

She was eventually discharged from the ICU to the ward with her tracheostomy in situ. Her GCS on discharge was 8 (E2VTM5). Plans were in progress for discharge to a nursing home for 24-hour care.

Pneumomediastinum has many aetiologies, and these include a ruptured oesophagus, trauma, an endobronchial fracture, mediastinitis, or iatrogenic as in this case. It is usually diagnosed with a chest X-ray, where radiolucent streaks are seen in the mediastinum along normal anatomical structures such as the heart and the trachea. If the pneumomediastinum is small however, it may only be detected by a CT. Its management is generally conservative and typically resolves with a reduction in ventilatory pressures and close monitoring. A notable exception is in patients who develop tension pneumomediastinum, where a mediastinotomy with drainage of air should be performed. ${ }^{1}$

\section{Learning points}

- If a tracheostomy is dislodged, a suction catheter can be used to railroad a new tracheostomy provided that there is an existing tract. Suction catheters are pliable, are unlikely to create a false lumen, and would follow the course of the pre-existing tracheostomy tract. A bougie should not be used as a railroading apparatus as it is rigid and can create a false passage. If this passage leads into the mediastinum, then subsequent attempts at ventilation can lead to pneumomediastinum, and this can be fatal.

- If the reinsertion of a dislodged tracheostomy is impossible, traditional endotracheal intubation should be performed as a safe interim measure while waiting for expert help (such as ear, nose and throat) to arrive. The exception is in patients who have had a laryngectomy.

Contributors MA is sole author of this article.

Funding The authors have not declared a specific grant for this research from any funding agency in the public, commercial or not-for-profit sectors.

Competing interests None declared.

Patient consent Next of kin consent obtained.

Provenance and peer review Not commissioned; externally peer reviewed.

\section{REFERENCE}

1 Caceres M, Braud RL, Maekawa R, et al. Secondary pneumomediastinum: a retrospective comparative analysis. Lung 2009;187:341-6.

Copyright 2018 BMJ Publishing Group. All rights reserved. For permission to reuse any of this content visit http://group.bmj.com/group/rights-licensing/permissions.

BMJ Case Report Fellows may re-use this article for personal use and teaching without any further permission.

Become a Fellow of BMJ Case Reports today and you can:

- Submit as many cases as you like

- Enjoy fast sympathetic peer review and rapid publication of accepted articles

- Access all the published articles

- Re-use any of the published material for personal use and teaching without further permission

For information on Institutional Fellowships contact consortiasales@bmjgroup.com

Visit casereports.bmj.com for more articles like this and to become a Fellow 